\title{
Redevelopment of Slum Area in Jakarta: Case Study The Impact of Gender Inequality on The Sustainable Livelihood Assets Post Resettlement from Kampung to Modern Apartment Style
}

\author{
Chusnul Mar'iyah \\ \{cmariyah2004@yahoo.com\} \\ Lecturer at Political Science Department, Universitas Indonesia
}

\begin{abstract}
This article is based on research to analyse the impact of resettlement on women's household livelihood in Kampung Pulo and Muara Baru, Jakarta. These urban slum dwellers have been evicted from the local government of Jakarta as part of flood mitigation program which include slum clearance for people who encroached the green zones. As a result of evictions, they got resettlement compensation into vertical housing, known as rusun, although they prefer cash compensation instead of resettlement. This paper describes how resettlement affecting women's livelihood in terms of their assets in two locations. Both women's household struggled over difficulty in adaptation for living in vertical housing, especially in regards of financial assets, human assets, physical assets, and social assets. However, Kampung Pulo dwellers are likely have better livelihood than people in Muara Baru.
\end{abstract}

Keywords: Livelihood Assets, Resettlement, Eviction, Gender Inequality

\section{Introduction}

In the global south, the growth of informal and slum settlements occurs as a result of lack access for the poor to obtain affordable housing, especially in a quite strategic location of the city. Hence, some urban poor dwellers are encroaching urban spaces even in precarious areas such us in flood prone location which usually zoned as green. The growth of slum settlement usually must face the risk of eviction and resettlement and become one of local government agenda, could be as part of beautification project or simply for disaster mitigation and restriction on land use.

People who live in urban environment have different vulnerability context, different capital assets, different patterns of access to assets for the poor, and different patterns of desired livelihood outcomes [1]. Global phenomena show that per year, about 15 million of people are affected by resettlement for both physical and economic displacement [2]. This condition is also part of urban poverty phenomenon especially for women who are likely more vulnerable. Women households who affected from displacement need a proper livelihood restoration because their attachment from previous neighbourhood have been uprooted.

In Jakarta, the high rate of population growth reaching about 10 million of people with its surrounding metropolitan area make Jakarta one of the most populates city in South East Asia, hence resulting in high demands of land for housing provision. Regional Development 
Planning of Jakarta mentioned that housing provision is challenged by the lack supply of affordable land in which leaving landed housing development and focused on public vertical housing provision, especially for resettlement purpose.

During 2013-2016 in Jakarta, several evictions happened as part of river normalization policy from local government to clear slum settlement in surrounding water bodies such as reservoirs and rivers. The level of evictions carried out by Jakarta Provincial Government ranked highest throughout 2013 to 2015 Throughout the three years, 2015 was the year in which evictions were carried out by afflicting the highest fatalities of 28,572 compared to 2013 with 17,533 people and in 2014 15,931 people.

As a result of evictions, government choose resettlement policy for the victims from horizontal housing to low budget vertical housing style also known as rumah susun or rusun. Adequate housing provision in the capital city has been one of the main concerns due to the lack supply of affordable land and public rusun turns out to be the main alternatives in providing housing for the low-income households. This condition worsened by the fact that Jakarta is suffering around 70.000 units of housing backlog every year (Department of Housing and Building Affairs of Jakarta, 2008) that makes local government concerns in providing public housing. According to Wakely [3] public housing is a dwelling provided by the government as a result of high number of homeless and slums.

On the other hand, resettlement policy for the sake of slum clearance and flood mitigation is not a flawless formula. For women particularly, resettlement might result in the loss of livelihood assets because their activities mostly rely on how they perceived livelihood assets which incorporated in certain spatial condition. The urban planning usually lacks gender perspective while slum relocation schemes required to be gender sensitive to make it successful and lack of conflict. Women empowerment approach is essential to cope with resettlement program.

According to Scones [4], the sustainability of livelihood happens when it can cope with and recover stresses and shock while enhancing its capabilities and assets. Empowerment is crucial to enable women to take equal place and participate equally in development process [5] to enhance their ability after facing difficulties in a new unfamiliar environment. This paper aims to analyse how does resettlement policy impact women household's livelihood assets in Jakarta, particularly in Kampung Pulo and Muara Baru. How does their livelihood assets are changing after being replaced? How does women cope with resettlement processes and what make it different in two cases?

\section{Theoretical Review}

\subsection{Eviction and Resettlement}

Vanclay [6] mentioned that resettlement refers to the process of planning which includes relocation of people, households, and communities from one place to another place, along with associated activities. Resettlement also might be negative experience for evictees when it displaced them without participation in planning process. Using state power intervention, eviction usually implemented in the name of "greater good for larger numbers" and carried out on worsen condition of livelihood for the displaced people [7]. Additionally, eviction typically occurs to expropriate land for urban renewal, redevelopment, and beautification project. 
Nevertheless, the practice of displacement every so often inevitable to avoid hazard especially when the location is prone to environmental risk. However, people who affected from displacement should obtain satisfactory and fair compensation such as: new land should at least be equivalent in productive potential where displaced people used to live, located in reasonable distance, and prepared for productive levels [6]

\subsection{Sustainable Livelihood Assets}

Livelihood assets has pivotal functions in urban settings to create sustainable urban communities. According to Carney [8], livelihood is "the capabilities, assets (including both material and social resources) and activities required for a means of living". The sustainability of livelihood relies on its ability to cope and recover from stresses and shock, also maintain and enhance its capabilities and assets for current situation and future [8].

Urban poor relies their living on the accessibility of livelihood assets which may differ from middle and upper class. Livelihood assets categorized in five classification: financial capital, human capital, physical capital, natural capital and social capital. DFID Sustainable Livelihood Framework also incorporating rights in relation to access to assets which also has connection with policies institutions, structures, and processes.

Sustainable livelihood assets have strong relation in recovering and empowering the victim of eviction and their adaptation with resettlement processes. Livelihood is not only about cash and materials they have but also about other assets such as social ties which include family and friends, skills, and physical assets that relies on their spatial location.

According Carney [8] in Rakodi, household livelihood assets have 5 different capitals:

1. Financial capital related on the availability of resources which enable them to accept changed livelihood strategies. It includes savings, credit, remittance, and pensions to enable household to invest in more productive assets. Financial capital is important because it relates to the ability of the households to improve their conditions.

2. Human Capital is labor resources including both quantitative and qualitative dimensions. Quantitative dimensions refer to the number of household members, time available to engage in income-earning activities. Qualitative dimensions refer to the level of education, skills and health status;

3. Physical Capital is produced assets as basic infrastructures which includes transport, shelter, water supply, energy, communications as well as housing, household goods, secure building, tools, jewelries, and equipment. It relates on all assets that could be used to increase productivity. Besides basic infrastructures, it also includes social infrastructure such as schools and hospitals.

4. Social Capital according to Narayan [9] mentioned that social capital includes "the rules, norms, obligations, reciprocity and trust embedded in social relations, social structures, add society's institutional arrangements which enable its members to achieve their individual and community objectives" [9] political capital might also be part of this assets which based on access on political process and decision making.

5. Natural Capital for urban poor somehow not as important as for rural community, however we can refer to land and its tenure security, food, energy, and water although there are some debates to define natural assets for urban community. 


\section{The Methods}

This research uses a qualitative method to understand the impact of resettlement policy on women's livelihood in two locations. The core collection method in qualitative is interpretative approach to seek some degree of understanding [10]. Using a case study design, this paper compares two different resettlement sites to know whether there are differences on livelihood asset's impact on women's household. The qualitative data collection gathered from both primary and secondary data.

For primary data, in-depth interview was used to dig information from the key informants using semi-structured topic guide. Secondary data was obtained from reports, articles, policy documents, laws dan by laws and media. For a case study, reliability and validity aspects especially in terms of internal and external validity might occur, hence we obtained data from several resources for the purpose of triangulation to reach saturation.

\subsection{Research Area}

This study used two case studies Kampung Pulo and Muara Baru in Jakarta. Using case study of this study have the advantage to understand the detailed account of the problem.

\subsection{Kampung Pulo}

Kampung Pulo is located in Jatinegara, East Jakarta alongside Ciliwung River. Kampung Pulo settlement had been existed for more than 60 years and had become the worst slum settlements in East Jakarta (BPS, 2013). For decades, Kampung Pulo always become one of the reasons of flood disaster in Jakarta because of its location in the river bank of Ciliwung which affected the flows of the water. During rainy season, river water level could rise to 1,5 meters -2 meters, flooding Kampung Pulo dwellers. According to Local Regulation No. 1/2012 about Planning, local regulation will be revitalized Ciliwung River's function, one of the ways is to evict illegal building and slum in its river bank.
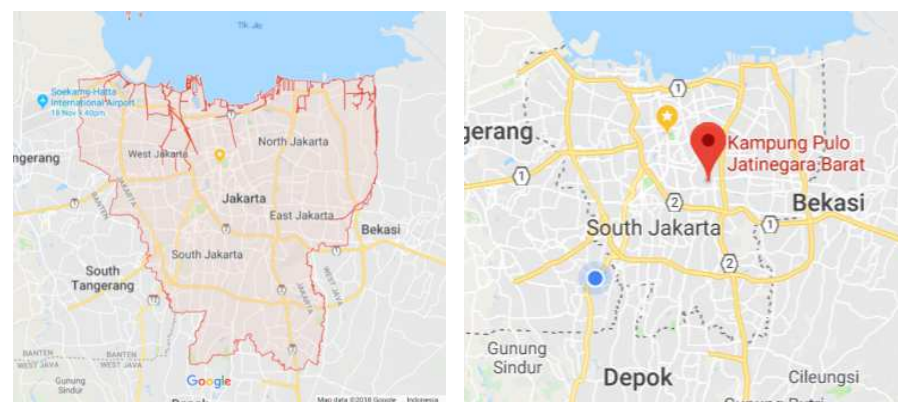

Source: Google image from https://maps.google.com/

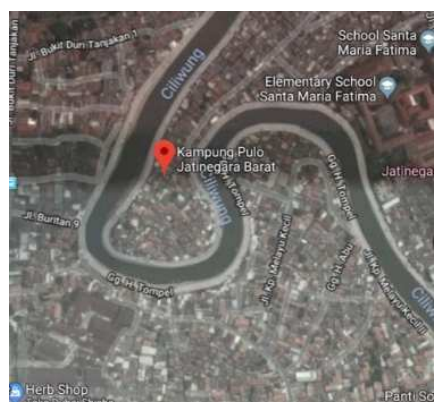

Fig 1. Map of Research Area 

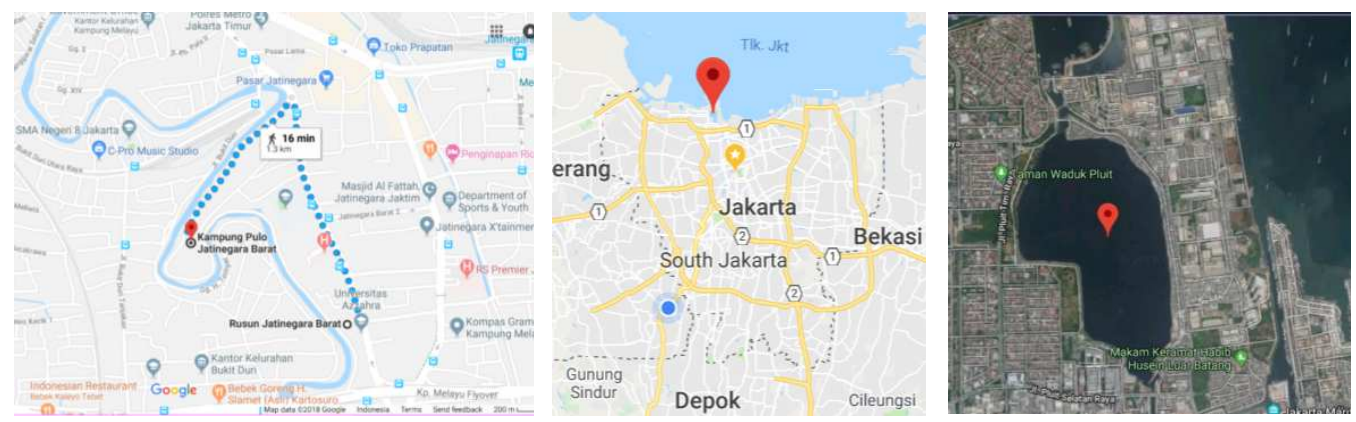

Fig 2. Map of Research Area 2
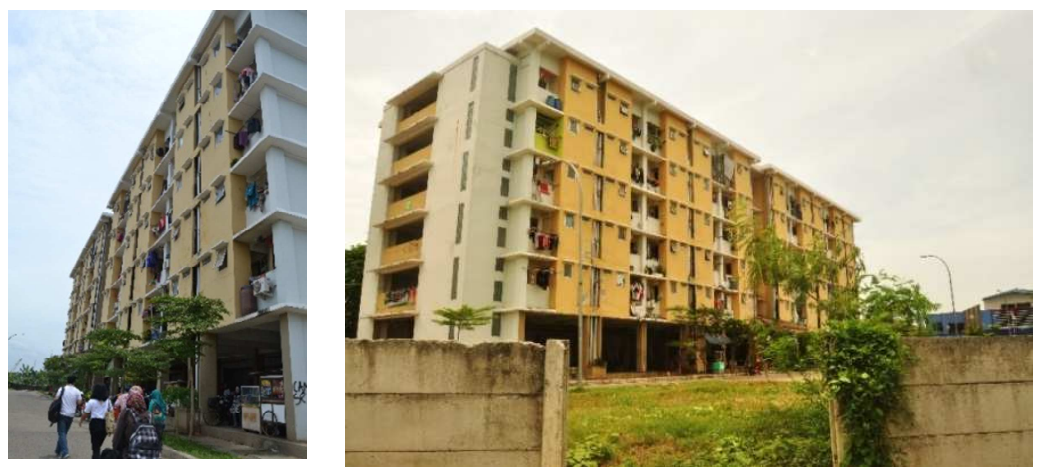

Fig 3. Resettlement Site: Rusun Muara Baru, North Jakarta

\section{Results and Discussions}

The government has the authority to conduct spatial planning by eviction. Based on Law No. 4 of 1992 concerning Housing and Settlements, it is said that the existence of an environment which 1) is not in accordance with spatial planning; 2) high density level; 3) the quality of buildings is very low; and 4) inadequate environmental infrastructure that can endanger the survival of its inhabitants, stipulated as settlements that need rejuvenation.

On a regional scale, the DKI Jakarta Provincial Government also has Local Regulation No. 8 of 2007 concerning Public Order. This regulation promulgates the DKI Jakarta Five Orders, one of which is the 'Residential Order' to mandate the demolition of stalls and illegal buildings. In Article 20 (d) there is a prohibition to build or settle under elevated roads, green lines, parks, along railroads, and other public places because it can damage the beauty of the city. Therefore, the policy of urban spatial planning through 'eviction' as found in Law No. 2 of 2012 concerning Procurement of Land for Public Interest, becomes something that cannot be avoided. The law was used as the basis for the legality of the government to conduct evictions to provide public facilities such as roads, water absorption, green lines, etc.

Meanwhile, the process of dismantling part or all part of the slums on state land in Presidential Instruction No. 5 of 1990 was declared as a process of regional rejuvenation. This 
is done as an effort to improve the quality of life of the urban poor through; 1) more efficient management of land and / or building use, in accordance with urban spatial planning; and 2) the provision of environmental facilities as an effort to improve welfare.

\subsection{Kampung Pulo}

Relocation process in Kampung Pulo took place in 20 August 2015, involving conflict between state apparatus and the dwellers. About 20 houses were destroyed in RT 01, 8 houses in RT 03, 31 houses in RT 04, and 7 houses in RT 05 [11].

The realization of this spatial planning began with the issuance of Gubernatorial Decree No. 163 of 2012 concerning Trace Development of Ciliwung River from the ManggaraiKampung Melayu Water Gate. This regulation was later extended with Kepgub DKI Jakarta No. 1281 of 2014, continued by Public Works Agency to procure land by emptying land that will be used for the construction of Trace. This development will dismantle \pm 518 houses in RW 01-03 in the Kampung Pulo area. Kampung Pulo finally became one of the locations of evictions under the pretext of normalization of the Ciliwung River.

After the DKI Jakarta Provincial Government issues Gubernatorial Decree No. 1281 In 2014, the Jakarta Provincial Government also held a socialization program aimed at bringing together the government and the community to achieve mutual understanding. The socialization held in April 2013, namely before the commencement of the 'eviction', between the residents and the East Jakarta Mayor, was explained that there would be a tone of compensation / compensation to the displaced people. This was stated in Pergub No. 190 of 2014 concerning Guidelines for Giving Compensation to State Land Cultivators by calculating "25\% x land area arable x NJOP (tax object sales value) for the current year". However, after two years of running, there was another socialization delivered by the East Jakarta Mayor in June 2015 which stated that there would be no compensation mechanism due to the existence of the people who were basically illegal.

The chance for a meeting between the community and the Provincial Government was directly obtained on July 24,2015 . The meeting resulted in the residents' agreement to do 'relocation' if there was a memorandum of understanding. Furthermore, the meeting on August 4, which was attended directly by Basuki Tjahaja Purnama (Ahok), Head of Jatinegara Subdistrict, Kampung Melayu Village Head, and Kampung Pulo residents, produced nothing because the headman (lurah) provided data that $80 \%$ of the community's land ownership status was illegal and did not require a replacement mechanism loss/compensation. Furthermore, on August 5 the negotiations led to a compensation scheme in the form of 1) having an official land certificate, receiving compensation 1.5 times the land area; 2) without a certificate but having an ID Card, is allowed to live in a rental flats (rusunawa);3) without a certificate and ID card, allowed to stay in a flat, but with the conditions. This agreement ended with the issuance of the third warning letter on July 6 for demolition. 


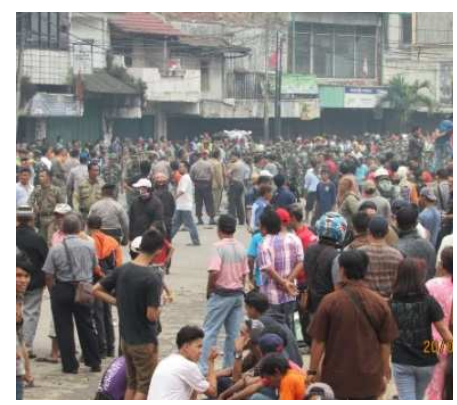

Clash During Eviction, Ciliwung Merdeka Documentation.

Source:

https://ciliwungmerdeka.org/wpcontent/uploads/2015/08/IMG_0 966-300x225.jpg

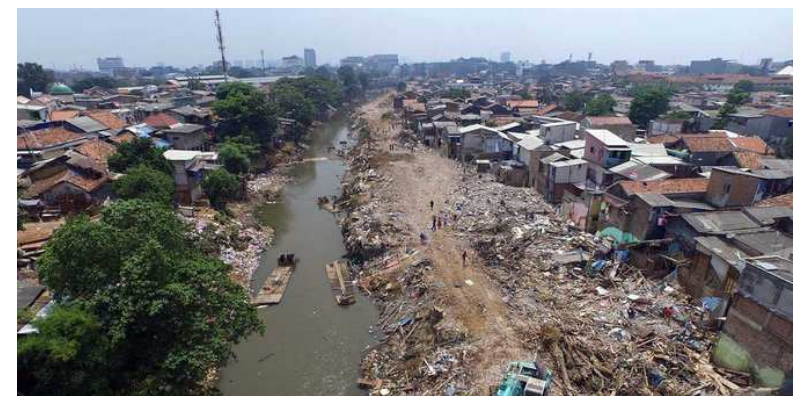

Kampung Pulo After Eviction took place. Source: http://cdn.klimg.com/merdeka.com/i/w/news/2015/08/28 /587194/670×335/video-ini-wajah-kampung-pulo-setelah7-hari-digusur-ahok.jpg

On August 20 2015, the Provincial Government was led by the Mayor of East Jakarta, assisted by 2,100 personnel starting to conduct evictions in Kampung Pulo. After an agreement was made between residents and the government, clashes continued between residents and the apparatus. Clash began with the consolidation process carried out by 1) the residents represented7 by a habib (religious leader) named Habib Soleh, 2) the Ciliwung Merdeka NGO, 3) the Jatinegara Police Chief, and 4) the Jatinegara Sub-District Head (Camat). All have agreed to demolish the residents' house who have obtained rusunawa unit, but the Head of Jatinegara Sub-district insisted on demolition of all settlements in the Kampung Pulo area. LBH Jakarta (2016) mentioned that there were 113 points of forced evictions that took place during 2015, of which the highest number of family heads (KK) occurred in Kampung Pulo, namely 920 households.

\subsection{Muara Baru}

- The relocation project was in 2003.

- The aim of the project was for normalization of water reservoa in Pluit area from maintaining water flow from raining season and from flodd.

- Government perspective as always stating that the people used the government land.

- The project include the srinking of water resorvoar from 80 hectar to 60 hectar.

- Citizens resistence movement based on the lack of socialization.

- Thera are at least 100 s people which is caused the delayed of the relocation. (Tempo, "dihadang warga, penggusuran di waduk pluit batal")

- The problesm of the srinking of the water reservoir has been the reclamation through putting the garbage into the water reservoir.

\subsection{Impact on Livelihood Assets}

- The issue of eviction in Kampung Pulo is already socialized by the government, however Kampung Pulo dwellers was being skeptical since they always heard this issue since 90s, but it never happened. 

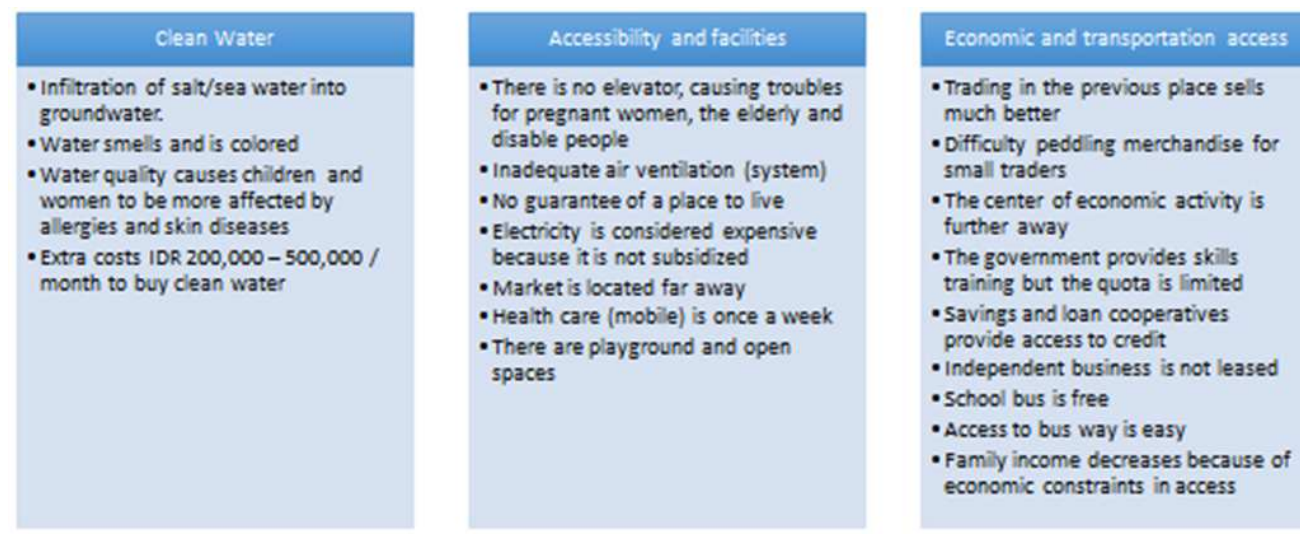

Fig 2. Critical Issues at Muara Baru Flats

Advantage of resettlement in Rusun Jatinegara

- Financial capital

For women household in slum area, the availability of financial capital is not that significant.

We can categorize some type occupation which based on financial sources such as:

1. Women who work as housewife. This type does not have active income and enough cash as they rely their revenue on their husband.

2. Women who work to help their husbands, but their work is not permanent. They do not work daily, some work only by request. Mrs. Santi and Mrs. Halimah from Muara Baru for example, their mainly activity is as their work as part of rusun management because their husband also work as rusun managers.

3. Women who work as bread winner. Their family relies on their income.

4. Women who work to hep the family and their job is as significant as their husbands.

5. Women who do not work and relied their income from their children.

However, the general job for slum dwellers is working in informal work such as small traders or works as street vendors hence their income is unstable.

\subsection{Financial Capital}

Impact after relocation

- Increase income stability, some facing discontinue

- Need time to recover after changes and shocks

In Muara Baru, some women work as housemaids in middle-upper residential in Pluit.

- Pak Ari and Ibu Anisa, a married couple who open a shop inside rusun block and open an internet café and selling snacks. They inhabit waduk pluit for years.

- They moved to Rusun Mara baru and for the first years, they stugled on adaptation 


\subsection{In Kampung Pulo}

- Due to flood, Kampung Pulo dweller live-in two-story houses where they put their important home appliances on the second floor.

- Kampung pulo dwellers had been adopted to flood

Market proximity

- Market proximity: market is in a close distance. After resettlement, market proximity is still close because resettlement site is near Kampung Pulo. However, Ibu Indah prefer to do grocery shopping from Kampung Pulo instead of from rusun as a result of the high building condition that create more difficulty for her. Market distance from Kampung Pulo is nearer because all she needs to do was just cross her neighborhood.

Skills training

- There are several skills training provided from Jakarta Government: make up trainings, cooking and culinary training, sewing training,

Home ownership and tenure security

- Mrs. Indah feels that although her previous housing condition in Kampung Pulo is not as safe as in rusun, she feels that it is so much better live in flood prone area that to live in a house that doesn't belong to her.

- Home ownership is matter for slum dweller. Rental tenure system does not make them feel secure about housing.

- They prefer cash compensation instead of resettlement. However, government did not allow cash compensation because they were squatting in illegal land or the government land. However, there is some differences between the have and the have not in using the government land.

- In term of human capital in the process of relocation, the women don't have opportunity to participate in the process because of the concept define that the head of household is the men.

- The social capital in the relocation has to promote an inclusive and participatory approach to urban resettlement schemes which impacting the poor. The communities affected by resettlement should have policy for incorporating the needs of women into each stage of the resettlement process.

\section{Kampung Pulo Dwellers}

- Resettlement creating income uncertainty

- From assets's function “ People adopt livelihood strategies to try to match expected resource availability with expected demand while also allowing for unexpected falls in resource supply or increases in demand. They do this by making savings in assets that ca be converted later to liquid or consumption assets, by borrowing to gain current resources at the expense of later debt repayment, and by adjusting their consumption patterns.

\subsection{The Loss of Community's Participation}

From the results of several successful interviews, the displacement of residents through river normalization programs encountered the challenge of changing the paradigm of the landed house to vertical dwellings (Flats/Apartments). Those who are relocated from 
riverbanks to flats take time to adapt. Then, no wonder if the government feels the work of socialization becomes a matter of long-winded and takes a very long time. In the end the city government chose the shortest and easiest way of eliminating community's participation on relocation and development planning. Similarly, taking care of the rivers in Jakarta so far that tend to eliminate the participation of the community as stated in the Regional Regulation No. 1 of 2012 on the Spatial Plan of 2030 and Regional Regulation No. 1 of 2014 on Spatial Detail Plan (RDTR), artificial cannall plan for the construction of lakes as well land use change in Kampung Pulo and Bidara Cina.

According to Sandyawan as chairman of Ciliwung Merdeka community who was successfully interviewed, the government's interest in development has also denied the ownership of static land in the form of Indonesia verpounding [girik (note), deed of sale, letter $\mathrm{C}$ and full certificate]. The government considered more on positivist proprietary rights that can change as the post-independence political system changes, so that the old one is considered invalid. Our informant, Mr. Baharuddin (40) a Pulo village officer also reinforced the initial information, that when Joko Widodo served as Governor of DKI Jakarta there has been repeated dialogue in forums established with the community. However, the original dialogue was intended to provide a solution, since 2014 has been transformed into a socialization of the relocation project and the community is required to move without any negotiations such as compensation, rental problems, the number of heads of families who occupy a flat, and the selection of rusunawa (flat) which is considered sufficient with their socio-economic activities so far.

Residents of relocation victims generally have to adjust to vertical residential culture that they had never imagined. They are not used to sort and pick out garbage, what they often do is throwing garbage through the windows, like what they do when living on the river bank. No wonder that the apartment manager imposed a fine for every waste that is not thrown in the place which has been provided. In our interviews with several residents of flats in West Jatinegara, those who were previously victims of the eviction of Kampung Pulo on the banks of the Ciliwung River, East Jakarta explained that they face financial problems when they have to be transferred to the flats.

The financial problems arise from the loss of their economic space. When living on the banks of the river, the wives in a family will be able to help the family economy by selling in front of their houses. The opportunity is lost when they have to be relocated to a number of flats, they can no longer sell in front of the flat unit they occupy, because in every flat has been arranged the use of space for the economy centrally. Each flat unit will have several places to sell. Our informant, Mrs. Dwi (40) who lives in Rusun Muara Baru (Muara Baru Flat), North Jakarta, explained that she has a shop selling various daily needs, including pulses and PLN electricity tokens, she explained that after moving to Flats there was a decrease in income. This decline occurred because previously she owned stall which is on the main roadside, and can give profit up to Rp. 1,000,000 / day. While the stalls opened in the flat can be one or two for each floor.

Mrs. Dwi experienced two times evictions. The first eviction happened when she lived near the Police Station around Pluit Reservoir. The informant had three rented houses which were evicted. The second eviction, when she moved somewhat inward (the first evicted house was just on the curb), was also evicted. Until then she was forced to move to Rusun Muara Baru (Muara Baru Flat). She also said that there was resistance from the people when the eviction was done by Satpol PP (Police) officers. Residents form barricades of resistance, throwing stones, but they are outnumbered in all aspects compared to the preparedness of the apparatus. It was also found that there was a landlord, named Mr. Budi, who had many 
contracts on the land of evictions. He did not want to accept the Rp.500 million as compensation, because the claim is Rp. 3 billion. Mr. Budi then also did not get replacement units (blacklisted), and according to informant, Mr. Budi now lives under the Bridge (Jembatan Tiga).

This condition illustrates that the relocation undertaken has not been able to provide a significant economic impact on improving the welfare of its inhabitants. The relocation policy undertaken impressed simply "moving people" without "moving their environment". Thus, what happens is that people moved to new places have to re-adapt to their environment, and their position gets depressed because of the difficulty of gaining access to the economy. Other facts that the authors managed to find such as Mrs. Laspiah (35), a housewife whose husband works as a welder. Before becoming a resident of Muara Baru Flat, Mrs. Laspiah and her family occupied the evicted land on the highway near Pluit Reservoir, and opened a welding workshop. After becoming a victim of eviction, practically her husband becomes difficult to get customers, because it is impossible for him to open a welding workshop in Muara Baru Flat. Her suffering does not stop there, she has four children, and her first child has experienced Dengue Hemorrhagic Fever (DHF) due to poor sanitation facilities in the flat.

\subsection{Poor Perspective of Government Spatial Planning and Spatial Management}

From the interview with Sonny Sumarsono, the temporary officer of the Governor of DKI Jakarta, the government generally has three main reasons for all eviction sites. First, the environment does not have a decent standard of living because of the prone to diseases coming through water and flooding. Second, the environmental conditions that are considered to be harmful for children and adults because prone to unstable and safe land conditions. Third, humanize human beings as well as create decent living conditions for the inhabitants. In addition we also managed to interview Panji Virgiawan, a member of Commission D of the PDI-P faction, as representatives of legislative members of the main party of government supporters. According to Virgiawan, the authority to move people from their homes is the authority of the executive, as set out in the RPJMD, RKPD and its implementation. The legislature only oversees the course of implementation.

The government in this cases both the executive and the legislative with a temporal perspective, seems only able to provide facilities and infrastructure without considering the network that has been built for so long. On the other hand, the government is also unable to create a guaranteed sense of welfare improvement especially for those affected by eviction. Relocation without considering the conditions and solutions for socio-economic community like this is actually considered to support the birth of structural impoverishment through the increasingly sharpened inequality. Frequently, physical clashes occur at the time of evictions and the relocation caused is considered as evidence that the government lacks of understanding about feelings of injustice experienced by society/community. Flats residents mostly work as laborers at Fish Auction Place, drivers, and so (informal sector workers). The informant complained about staying in the flat because it was "poked in" by the officers for things that were not understood. They are often asked for KTP (Identity Card) and KK (Family Card) for unnecessary matter. The informants also complained when they had to be photographed holding a flat information board, like a photo of a prisoner (mug shot).

From the interviews with Mrs. Sumartini, a Rawajati resident who was relocated to Marunda Flats on December 6, 2016, most of them complain about relocation to Marunda area (North Jakarta) which is very far from Rawajati (North Jakarta). The residents even asked the Provincial Government of DKI Jakarta to be moved to the Cipinang flats that are felt 
closer to their previous activities. In addition, according to field conditions Rawajati is located in South Jakarta that is concentrated in residential areas, while Marunda in North Jakarta is concentrated in the industrial and trade sectors. . So it takes time for those who were previously dependent on their economic revenues to sectors which are closer to home and the social base of the neighborhood. Jakarta Provincial Government is seen not able to consider this complexity from the placement of residents as eviction victims to the location of the flats available, since the beginning of the flats look oriented physical development, passive container and remove the connectivity elements.

For Mrs. Sumartini, the treatment of rental fee at the price of each different floor (the higher the floor, the lower the rent cost, the difference per floor is Rp10.000) is enough to cause a mark. With rental fee per month as much as Rp234.000 / month, payment is made through Bank DKI, each family has their own account. Although there are also programs from the Provincial Government to provide free rent in the early months for our informants who live in the flat, about the first two months, yet this is still a very partial and temporal approach. With the condition of each flat that has two rooms, inside bathroom, in-except for the ground floor with separate bathroom, now the flat does have a concept as a shelter from the heat and decent rain in urban areas. On the ground floor of the flat, it has actually been designed by the government for shops and warehouses, but due to the flood of relocation residents, the ground floor is currently used as a residence.

As for the residents of the evacuation placed in Muara Baru, the complaints we managed to catch were not much different from other flats. Before moving, they do not have to pay for rent every month. They only need to pay the electricity bills that the amount is not too much. Meanwhile, when they have become victims of eviction, and occupy Flats units, they inevitably have to allocate money for lease payments. If payment arrears arise for more than three months, then the unit will be taken back by the manager and the occupants are welcomed to find a new residence.

Eviction on behalf of development, beauty, or on any behalf should be reviewed. What is the function of the state towards the welfare of its people? What is the function of the ruling regime in serving the public as a manifestation of the daily politics of its people? Where is the state present in serving the needs of its people? How to change the paradigm of development towards participative and also pay attention to condition of citizen? It needs to be reviewed the homogeneous city development, even throughout Indonesia which cities are built as "City Shop" without heterogeneous characters. The Jakarta City Leaders should review the city's development by maintaining the villages that can give the soul to the city of Jakarta. Otherwise, the city of Jakarta will only be a daytime city and concrete without a soul, because the population is mostly evicted in the suburbs (Mariyah, Sihombing, Amanda, \& Jamalianuri, 2015).

From the study produced the toolkit for government. The toolkit provides guidance to empower women in resettlement situations including (Juanita, chusnul, et.all.):

- initially identifying female stakeholders,

- encouraging women to participate in consultation and tackling barriers to their participation,

- ensuring appropriate gender-balanced data collection,

- prioritising women's needs and requirements, including safety and livelihoods,

- ensuring the smooth transition to resettlement housing during the implementation stage which takes account of the specific needs of women,

- establishing mechanisms for monitoring and evaluating the performance and outcomes of resettlement and measuring its impact on women affected. 


\section{Conclusion}

This research contributed the recommendation that relocation policy needs to be significantly reconsidered. At the level of pre-relocation, local government needs to conduct thorough and objective mapping of the kampungs in Jakarta, involving experts in the field alongside local residents especially women perspective. Communication of the policy needs to be conducted effectively so that the residents targeted for resettlement comprehend the nature of relocation and understand the lifestyle changes of superblock habitation. A participatory planning approach that involves residents in decision-making would facilitate a bottom-up collaboration with government and help to mitigate against the worst effects of relocation toward women's members of the neighbourrhood .

A more inclusive approach to relocation policy would also help to strengthen capabilities post-relocation, to ensure security guarantees, education and health services, transportation access, and most importantly economic centers for the citizens to maintain livelihoods especially gender livelihoods.

As in the report of this study by Warwick and UI, recommended that "Recognising that women very often have different roles and responsibilities to men and as a result, different needs and requirements it seeks to address the asymmetries and discrimination that women face and encourages the mainstreaming of gender, by highlighting how women's needs and perspectives can be incorporated more effectively into all stages of the resettlement process. At the same time, it should be acknowledged that women are not a homogenous entity, but differentiated by socio-economic factors such as age, race and ethnicity, marital status, disability and levels of income. Whilst it does not cover all strategic and operational aspects of resettlement, this toolkit aims to establish why it is important to consider gender in all stages of the process and provides a step-by-step approach to including women in the preparation, planning, implementation, monitoring and evaluation of post-eviction resettlement."

Overall, relocation is not just about moving people from one place (kampungs) to another (superblock/high-rise apartments), but also an opportunity to enhance lives and empower citizens especially women. Social responsibility, justice and equality in weelbeing or livelihood's dimensions are vital, as is a gender perspective.

\section{Acknowledgement}

This work derives from a foreign joint research project as a collaboration from Universitas Indonesia and University of Warwick, entitled "The Empowerment of WomenHeaded Household in Jakarta's Slum Area: Achieving Gender Equality and Creating Inclusive, Safe, and Sustainable Development" funded by the Kementerian Riset, Teknologi, dan Pendidikan Tinggi Republic of Indonesia. Other members of research team: Jamalianuri, Hasbi Rofiqi, Irhamna, and Prasetyo which helping us in data collection, analysis, and administration, also thanks to "Women, Politics, and State" and "Urban Politics" Class of 2016-2017 who helped us in providing data from their class reports. 


\section{References}

[1] D. Halden and J. Farrington, Rural Accessibility. Edinburgh: Scottish Executive Central Research Unit, 2002.

[2] B. Terminski, "Environmentally-Induced Displacement: Theoretical Frameworks and Current Challenges," 2012.

[3] P. Wakely and E. Riley, "The Case for Incremental House," Washington DC, 2011.

[4] Scones, "Sustainable Rural Livelihoods A Framework For Analysis," 2001.

[5] S. Longwe, "Gender and Awareness: The Missing Element in the Third World Development Project, in Changing Perceptions," 1991.

[6] D. Jijelava and F. Vanclay, "Legitimacy, Credibility and Trust as the Key Components of a Social Licence to Operate: An Analysis of BP's Projects in Georgia," J. Clean. Prod., 2017.

[7] M. M. Cernea, Risks Safeguards and Reconstruction: A Model for Population Displacement and Resettlement. Washington, D.C: The World Bank, 2000.

[8] Carney, Sustainable Livelihoods: What contribution can we make? London: Department for International Development (DFID), 1998.

[9] D. Narayan and L. Pritchett, Cents and Sociability: Household Income and Social Capitalin Rural Tanzania. Washington DC: The World Bank, 1997.

[10] S. Van Thiel, Research method in public Administration and public Management; An Introduction. New York, 2014.

[11] "Ciliwung Merdeka." [Online]. Available: https://ciliwungmerdeka.org/wpcontent/uploads/2015/08/IMG_0966-300x225.jpg. 